\title{
13 The Kenyan General Elections of 1997: Implementing a New Model for International Election Observation in Africa
}

\author{
M. Rutten
}

INTRODUCTION

In 1992, Kenya held the first multi-party elections since the de facto single-party elections of 1969. Church leaders had started campaigning for the return of the multi-party system in the beginning of 1990 . Politicians, NGOs and the Kenyan public at large followed their example. Even more important, by November 1991 the international donor community also openly pressed for political as well as economic reforms and threatened to withhold aid. The following month President Daniel arap Moi announced the withdrawal of section 2(A) of the

Constitution, making Kenya a de jure multi-party state again. New political parties were launched. finally, on 29 December 1992 Kenya followed the footsteps of Zambia, which had, among the English-speaking African countries, heralded the transition from single to multi-party politics in October 1991 (see Andreassen et al. 1992).

The Kenyan 1992 elections were characterized by widespread allegations of irregularities, such as the stuffing of ballot boxes, destroying of opposition votes and count-rigging (see Barkan 1993; Mulei 1996; NEMU 1993; Weekly Review 1993; Africa Confidentral 1993). Local observer groups had united in the National Electoral Monitoring Unit (NEMU). They trained and 
deployed some 8,000 domestic observers throughout the country.

The international community observed the elections in the usual way: election observers from all over the world were flown in some days before election day (29 December) and left shortly afterwards. The two most important outside teams were the Washington-based International Republican Institute and the Commonwealth team. In addition, national delegations from Denmark, Egypt, Germany, Japan and Switzerland were sent. Still, there were fewer than 200 international observers for 7,000 polling stations. Coordination of efforts by the foreign missions was minimal (see Afreca Confidential 1992). Also, 'Neither the foreign nor the local observers groups had the capacity or resources to investigate comprehensively rigging allegations. Consequently they reported only the most blatant and easily verifiable irregularities' (Africa Confidential 1993).

Accusations of 'election tourism' were also made (see Geisler 1993: 615). In preparation for the observation of the 1997 elections, it was thereupon concluded by the donor community that a more coherent and thorough approach was needed to reach an objective overall judgement concerning the way elections are conducted.

\section{THE CREATION OF THE ELEGTION OBSERVATION CENTRE}

In the months of May and June 1997, member states of the DDDG (Donors for Development and Democracy Group) -24 Western donors ${ }^{1}$ - held a number of meetings and decided to install an Election Observation Centre (EOC). This small secretariat was to coordinate all activities by and for the DDDG member states' representations in Nairobi. ${ }^{2}$ Its major purpose was to provide information to the DDDG missions concerning election rules, constituencies to be visited and what to observe, and to coordinate the travel plans of the DDDG missions.

The Western donors made funds available for a mission to design the EOG and to provide a workplan. The main bottleneck was the uncertainty regarding the date of the election. In principle it should have been held in 1997, five years after the 1992 elections and at the end of President Moi's first term. The elections could be held within a period of some two months after the president decided to dissolve parliament. As a result, the donor group needed to prepare themselves for observing the elections somewhere between August 1997 and April $1998 .^{3}$

The main rationale for collaboration was to avoid a duplication of efforts. Another element was dissatisfaction with the traditional, short-term election observation by hastily prepared teams of international observers. Moreover, it had become more clear in recent years that an election is more than polling day: it includes many phases such as the issuance of ID cards, registration of voters and nomination of candidates. Also, information concerning the election process provided by the relevant authorities and media in Kenya lacked credibility. A need was felt among donor-country representatives to look for an alternative model for election observation. The Dutch took the lead and convened a meeting on 28 May to discuss the creation and terms of reference for a 'DDDG Election Observation Secretariat'. Interested parties were Denmark, USA, the EU commission and the UK. Except for the latter, all showed their immediate willingness to combine both funds and personnel in the establishment of a secretariat. ${ }^{4}$ It was decided that a next step would be to decide on what resources would be required for the secretariat to function properly and under which precise conditions.

In July, two consultants, Marguerite Garling (EU) and Judith Geist (USAID), provided a proposal for the set up and operation of the Diplomatic Election Observation Secretariat. Three models for election observation were discussed: a) 'Do-itYourself'; b) small coordinating Secretariat; c) UN coordinated formal observation.

In the first model the missions would gather information by themselves. At best they would pool their observers and share the information collected. In the third model, observation would be along the traditional lines. A UN-supplied coordinating team would run an independent office and provide a full range of services to the diplomatic community. This option was considered to be a rather inflexible, costly and unsatisfactory one. Thus, in the end, it was recommended to embrace the second model, for two main reasons: 1) some DDDG members had indicated that staff resources were limited and that additional observer capacity would be welcomed, and 2) the UN option would take too much time to establish and fund a well 
functioning unit, while the elections were near. finally, experit ence had shown that a UN unit would have difficulties in craft. ing a joint verdict on the process and outcome of the elections.

The structure, functioning and necessary resources of Model 2 were outlined by Garling and Geist as follows: the resources to run it should be acquired from individual diplomatic mis sions. It was proposed to contract a coordinator with overalk supervision, liaison and public relations responsibilities; an in formation and analysis officer; three or four research assistants; and an office manager. The secretariat should assist in the pro* duction of observation forms, news summaries, briefing material, and a deployment strategy as well as with actual field observation. This intermediate model between 'Diplomats Do'It-Yourself and 'UN Stand Alone' was somehow drawn on a' model employed in the Ethiopian 1995 elections, but foremost a new experiment.

By early July it became clear that the UN had no intention of setting up a UN electoral Unit during Kenya's 1997 General Elections. This position was explained to the DDDG by a UN representative. He also stressed the need to support local observers. The UN was considering several options in this respect and was pleased to learn that the donors intended to provide financial assistance to domestic groups. That same meeting the donors accepted the consultants' proposal almost in full length except for the hierarchical structure of the Election Observation Centre. Instead they opted to divide responsibilities between at least three to four coordinators. As indicated by the donors in the Terms of Reference to these coordinators, the main tasks of the EOG were to:

- Collect and analyse material concerning election rules and regulations, constituencies and the location of polling stations;

- Monitor local newspapers and journals;

- Liaise with the diplomatic missions of the DDDG;

- Provide advice to the DDDG missions on which constituencies would merit visits and guidance on what to observe;

- Produce checklists for diplomatic observers, for each phase of the election period;

- Coordinate observer travel plans;

- Maintain and distribute records of observer reports;
Coordinate travel planning of the DDDG missions;

- Maintain close contact with domestic observer organizations,

other international observer teams, if any, and with the

political parties;

Maintain close contact with the Electoral Gommission.

The EOC was not conceived as a formal entity in its own right, but rather as a tool that the DDDG used to gain a maximum amount of shared information while economizing on diplomatic the spent in official efforts to obtain such. EOC members were to refrain from making public or press statements. At the same time the EOC needed to be transparent about its intentions and working methods to the Electoral Commission of Kenya, the political parties, the domestic observers and the civil society actors at large.

\section{KENYA'S 1997 GENERAL ELEGTIONS: THE GONTEXT}

-

The context of the 1997 General Election in Kenya could be characterized as one of rising tension since the beginning of that year. Cabinet reshuffles resulted in the return of certain Thinisters known to be 'hard-liners' while other, more modest and reform-oriented ministers left. Opposition parties, civil society groups and religious institutions combined efforts and intensified their calls for the abolition of certain repressive laws and for constitutional reforms to create a (more) level playing field before the 1997 General Elections. For this purpose the socalled National Constitutive Assembly was created and had its first Plenary Session in Limuru on 6 April 1997. In the following months its executive arm, the National Convention Executive Committee (NCEC) organized and channelled mass protests to an extent that the government seriously felt threatened. The clashes along the coast which erupted in August and September, whereby especially non-KANU groups became victims of attacks thought to be organized and instigated by (local) KANU-politicians, further deteriorated the situation. It has been claimed that this tragedy was part of an initial phase. of a larger state-sponsored plan to undermine the constitutional reform movement. ${ }^{5}$ However, international protests and ongoing national pressure finally resulted in the adoption of a 
minimal reform package through the Inter-Parties Parliamentary? Group (IPPG). Though criticized by some sections of the opposiz: tion, this package enabled the restoration of a more calm envir onment. For example, freedom of political demonstrations and gatherings was allowed, and Safina (a new opposition party) after a long period of delay and uncertainty, finally registered. It was against this background that Kenyans voted on: 29 December 1997 for a new five-year period of local and parliamentary government and for the Presidency.

\section{ACTIVITIES PERFORMED BY THE EOG}

By the end of October 1997 the British coordinator arrived and started to prepare the Election Observation Centre (EOC) for operation. He met with a large number of diplomatic missions, Kenyan politicians, domestic observer groups and civil society NGOs, and arranged practical issues such as financing, housing, equipment, collection of election profiles, and relevant documentation from back-issues of newspapers and weekly magazines. By the second half of November the EOC started to become fully operational. All coordinators had arrived and the coordination of election observation by the 24 DDDG missions was fully put into practice. Within the EOC specific tasks were attributed to the coordinators and staff members, as shown in Table 13.1.

The 1997 Kenyan elections can be subdivided into five distinctive phases:

1. Registration of voters (conducted from 22 May to 3 July 1997);

2. Internal political party elections to decide on their candidates ('party primaries') (late November-early December);

3. A two-day period for officially nominating these candidates to the Kenyan Electoral Commission (2-3 December presidential and 8-9 December local and parliamentary candidates);

4. The campaign period (10-28 December); and

5. Election day (including counting of the votes), 29 December and following days.
13 1 Attribution of tasks, DDDG Election Observation Centı $\mathrm{e}^{6}$

\begin{tabular}{|c|c|c|c|}
\hline & $\begin{array}{l}\text { Co ordinator } \\
\text { for }\end{array}$ & $\begin{array}{l}\text { Political } \\
\text { party }\end{array}$ & $\begin{array}{l}\text { In relation } \\
\text { with }\end{array}$ \\
\hline David Throup & Central & $\mathrm{DP}$ & $\begin{array}{l}\text { Electoral } \\
\text { commission }\end{array}$ \\
\hline Judith Geist & Nyanza & $\begin{array}{c}\text { FORD-K + } \\
\text { FORD-A }\end{array}$ & Donors \\
\hline Marcel Rutten & South Ruft & $\mathrm{SDP}+\mathrm{KSC}$ & $\begin{array}{l}\text { Media } \\
\text { IPPG }\end{array}$ \\
\hline $\begin{array}{l}\text { Palle Svensson } \\
\text { Sabitha Raju }\end{array}$ & $\begin{array}{l}\text { Ukambanı } \\
\text { Coast }\end{array}$ & $\begin{array}{l}\text { FORD-P } \\
\text { NDP }\end{array}$ & $\begin{array}{l}\text { IPPG } \\
\text { Gender }\end{array}$ \\
\hline $\begin{array}{l}\text { Sabitha Raju } \\
\text { Catherne Duhamel }\end{array}$ & $\begin{array}{l}\text { Coast } \\
\text { Central Ruft }\end{array}$ & KANU & Human rights \\
\hline Jennifer Loten & Naurobi & Ford-P & NGOs \\
\hline EOG & $\begin{array}{l}\text { Northern Rift } \\
\text { + NEP }\end{array}$ & Safina & \\
\hline $\begin{array}{l}\text { EOC } \\
\text { EOC }\end{array}$ & $\begin{array}{l}\text { North of Eastern } \\
\text { Western }\end{array}$ & & \\
\hline
\end{tabular}

Note NEP $=$ Northeastern Province

\section{Registration of Voters}

Refore the official start of the EOC its coordinators witnessed veraluthe voter registration process in somed that up to two million ation of voter registration concluded 18 and 23 had not been young Kenyans between the ages of 18 and thus were denied issued with their Nat their franchise.

Re right to exercise their franchise. 22 May 1997 and was supRegistration of voters started on 22 Marted with controversy posed to last 35 days. The exercise started with nomic Review over the use of old and new identity cards (Eom areas people 1997: 30). Allegations were made that in certain areas poople were dened registration on the basis of ethnicity (sele, Nairobi Revnew 1997a: 20). In other constituencies (for example, Nain ini Westlands) very high rates of registration were recorded or inza tially wrong voter cards issued (Luo districts of Nyanza Province). Faced with numbers far below the target, the Electoral Commission chairman, Mr Chesoni, extended the voter registration period by a paltry two days and then grudgingly added another few days, with 3 July being

finally slightly over 9 million people registered. 


\section{Party Primaries}

Deployment plans and checklists for observation of the party primaries were ready by the end of November. Detailed infor. mation on each constituency had been collected from newspapers, weekly magazines and knowledgeable individuals. If was used in the analysis for determining which constituencies needed priority in the observation exercise. All of this informat: tion was provided to the diplomatic observers in a meeting on 24 November. Representatives of domestic observer groups were also present at this meeting. They shared their knowledge and experiences with the donor community.

Mainly the British, Dutch and Canadian diplomats observed? the party primaries. Based on reports for KANU, DP, NDP and Ford-K primaries from some 24 districts, the EOG produced a short report, which was presented to the DDDG. It was concluded that in general the primary process was done fairly similarly to the one in 1992. Some 2 million Kenyans participated in the selection of their parties' candidates. Among the main differences, though, was the less important role played by the Provincial Administration. Problems were greatest in urban areas. Notwithstanding this observation, and despite violence in Likoni, and along the Trans Mara-Kisii border, the November-December 1997 party primaries were conducted in an environment much less constrained by ethnic violence than in 1992.

\section{Nomination of Parliamentary and Civic Candidates}

After the party primaries a detailed 'plan of action' was produced by the EOG to streamline the activities and division of labour. Nomination observation forms were produced and handed out, together with constituency profiles, and other relevant information, to the international observers. Certain constituencies had been ear-marked as potential problem areas needing observation. On 8 and 9 December, some 11 Western missions participated in the observations. Over 50 observers visited a similar number of constituencies. Again Dutch, British and Canadian observers provided the bulk of the observers. Observation forms had to be returned to the Gentre by 10 December. If serious incidents happened contact was to be made with the EOC. The EOG received complaints by political parties about problems in Siaya and Nandi areas; diplomatic bservers and the EOG made checks in those districts. The DDDG Chair contacted the Electoral Commission of Kenya and summarized the international observers' concerns for Nandi, where opposition parliamentary and civic candidates were denied clearance of their nomination papers. In the end, no cases of candidates being barred from the nomination irocess were reported for this area. In contrast to 1992, the nomination process on 8 and 9 December was more peaceful and conducted in greater accordance with the regulations. Most nomination centres opened on time and were efficiently organized. This time problems seem to have come from interference by party headquarters. Sometimes at the last moment attempts were made to replace the official candidate by another person (such as in the case of KANU in Kajiado Central and South constituencies).

\section{The Campaign Period}

On 10 December the Kenyan general elections 1997 campaign period officially started. The EOC informed all missions in preparation for the campaign observation and handed out campaign rally checklists and information packages. Deployment plans for the period up to 21 December were distributed on 15 December. It also indicated areas where the EOG would like to send diplomatic observers.

The EOG collected details on campaign programmes for the political parties. This was hard to obtain, and mainly restricted to the presidential candidates. Likewise, dates, venues and times could easily change. This hampered the observation of the campaign period. Besides, the ability to hold political rallies and access to the media are an important aspect of observation. From July 1997 the Kenya Human Rights Commission (KHRC) in partnership with 'Article 19' (the International Centre Against Censorship, based in London) monitored the (stateowned) Kenya Broadcasting Corporation (KBG) radio and television coverage of political activity in the period leading up to the 1997 General Election. KHRG published monthly reports in both a quantitative (air-time for political parties) as well as qualitative sense (negative/positive) (see KHRC and Article 19). 
During the months of July, August and October, coverage of KANU and President Mol took up more than 80 to 90 per cent of $\mathrm{KBC}$ television and radio reports. By contrast, -its coverage $\mathrm{of}$ the opposition was some 5-10 per cent only - and mostly negative. Following the IPPG reforms in early November and the subsequent amendment of the Kenyan Broadcasting Act, re quiring $\mathrm{KBC}$ to maintain a fair balance in allocating air-time between the different parties, the time allocated to the opposit tion increased dramatically, rising from 10 to 32 per cent in the last week. However, 96 per cent of opposition coverage in week four was negative. From the start of the official campaign onwards, KBC Television and radio returned to giving a dispro-: portionate amount of time to KANU and President Moi. Coverage of the opposition parties and candidates was much more equal in the print media. Journalists were permitted to record the process and to take photographs. International observers witnessed their presence on the nomination days and during the campaign period.

International observers witnessed bribery and intimidation of minority party supporters in many constituencies throughout the election period. Nevertheless, in general the electoral process was considered more peaceful than in 1992. So-called KANU zones, constituencies declared to be 'no-go' areas by KANU politicians, were more or less absent this time. In opposition areas threats were mainly directed at KANU activists. Few opposition meetings were prohibited or interfered with by the Provincial Administration or police. There were exceptions, however, including the use of tear gas against opposition presidential candidates and life threats to, among others, Mr Kandie, the opponent to President Moi (see Andreassen 1998). Female candidates in particular complained that they were singled out for attacks purely on the basis of their gender.

\section{Voting Day}

Towards 19 December, the workload at the centre reached its maximum levels. Because of public holidays in the week before the General Election Day the time-span to finalize the deployment plan, prepare the field Guidance Manual and the 'Observation Kit', and organize an instruction meeting with all observers was minimal.
The Diplomatic Election Observers field Gundance contained general guidelines for observers (for example, code of ethics, dealings with the press, security) and gave detailed information saicerning the Kenyan electoral process (for example, election rules, voting and counting procedures and irregularities). It aiso included election observation forms, investigation and rejorting guidelines. The EOG had made arrangements for the 6sservers to immediately report to the Centre on 29 December ifserious incidents occured. The 'Observation Kit' contained, among others things, constituency profiles, map of the area, Tists of returning officers, Electoral Commissioners, district electoral coordinators, polling stations and team deployment details. Also included were the official Electoral Commission of Renya Election Manual, IED Election Observer (Training) Manual, vehicle posters, an international observers T-shirt and Electoral Commission of Kenya observer badges. Observers also carried a letter of accreditation. On 19 December all interhational observers were instructed. That same day the DDDG also informed the international press of their plans for the observation of the elections. By 24 December all materials had been handed out to the diplomatic missions.

Most diplomats left one or two days before 29 December, so as to witness the opening of the polling stations, scheduled at 6.00 a.m. However, the distribution of ballot papers was flawed at three stages: first, from the printers in Britain, secondly, from the central stores of the Electoral Commission in Kenya; and finally by returning officers in many constituencies. ${ }^{7}$ As a result many polling stations opened late. The Electoral Commission, in an attempt to overcome this problem, extended the poll to Tuesday 30 December. Unfortunately, this announcement came rather late and was contradictory, creating considerable confusion in many areas.

\section{The Count}

The count of the Kenya 1997 elections started on 30 December and was done at constituency level in a central counting hall. There were too few counting officials and the count took far too long: in certain areas up to a week. Still, the count was conducted in a fair and transparent manner in most constituencies, and intimidation and/or rigging were witnessed or are 
suspected to have taken place in about 15 constituencies. Incidents reported include attempts to smuggle filled ballot papers into the counting hall; arrival of ballot boxes after the count had begun, usually without party seals or agents; count ing clerks caught attempting to spoil ballot papers; deputy re? turning officers kidnapped; and the mishandling of empty ballot papers in the possession of Commission officials. The EOC coordinators witnessed in person particular serious irregularities at the count of Westlands constituency. Among the problems? observed were interference by State House officials; change of final result in favour of the KANU candidate for parliament; refusal of a recount; attempts by the election officials to remove the ballot boxes without sealing them; and opening all the boxes and intermingling of ballots from different polling stations to reduce the number of ballot boxes. It was claimed that the latter was done on the instruction of the Electoral Commission because of lack of storage capacity. ${ }^{8}$ In conclusion, especially with reference to this case, the idea of having a small secretariat with observing capacity worked very well.

\section{Reporting the Observations}

While following the Westlands situation closely the EOC staff members entered data from 500 polling stations which had been gathered by more than 150 international observers who had visited 115 constituencies. On 2 January they had all reported back to the EOC for a debriefing session. Experiences were shared in small regional groups and in plenary discussions. This qualitative information was added to the quantitative analysis of the observation forms. By 4 January, the EOC finalized its report on the overall conduct of the elections, including information on serious irregularities. Graphs and tables showing the 107 over 103 victory for KANU were also included.

The final report was forwarded to the DDDG missions. It concluded that the EOC was of the opinion that the win by President Moi of the presidential election was, though at some stages flawed, 'acceptable'. The most important conclusion, however, was that in ' 5 per cent of the Parliamentary contests, the irregularities in the poll and count were so great as to invalidate the elections in these particular constituencies and, consequently, the legitimacy of the overall KANU majority in the
National Assembly'. According to the EOG in at least three constituencies (Westlands, Kitui West and Changamwe) the count had been rigged in favour of KANU. In other words, the 107-103 majority should have been a 106-104 victory for the opposition. A meeting with all ambassadors was held the hext day to discuss the report. It was agreed to follow up on certain issues raised by the meeting, such as collecting information from domestic observers to verify and extend the information on a number of constituencies, which had been carmarked as having suffered from 'serious irregularities'. On 8 January the draft report was discussed with a core group of the DDDG. Adjustments were made along the lines of editing the text to maximize clarity, update or correct information on the outcome of the elections and to rephrase the text along more diplomatic lines. For example, the 'legitimacy' issue was dropped. Among the arguments used was the sub judice rule. ${ }^{9}$ Publication of the report might interfere with coming petitions by contenders against the outcome of the elections. It was agreed that following the last type of adjustment the internal EOC report would be turned into a DDDG report and should be named as such. The EOC members finalized this version on 9 January and handed it in to the chair of the DDDG for distribution among its members. It was hoped that in one week's time the report could be made public. A small delegation of ambassadors would visit the Electoral Commission for this purpose as well. The political parties were also earmarked as among the likely receivers of the report.

Most members of the EOC left by the middle of January. A few stayed and continued gathering information from domestic observers, journalists and representatives of political parties, churches and civic rights NGOs. A number of constituencies were revisited again to do follow-up research to obtain more detailed knowledge of the elections. One major activity was the screening of events in the Molo and Kilgoris constituencies. fights had started in the Laikipia area, which had at a certain stage an undeniable political character and had spread by 25 January to the Njoro area south of Nakuru in Molo constituency. fights between Kalenjin and Kikuyu groups were witnessed and taped on video. These findings were reported to the international press. finally, by late January a third version of the international observers' report was sent to all missions. This 
version had been slightly adjusted and the British High Commission acted as chief editor. Except for a few lines with references to the 1992 elections, no essential changes had becn made to the version handed in by 9 January. The main change was that recommendations to the ECK for coming elections had become an integral part of the report again. It seemed as if the report had simply been shelved. It took another two weeks until the report was made public and discussed in the Kenyan press on 15 February.

\section{EVALUATION OF PERFORMED ACTIVITIES AND SUGGESTIONS FOR IMPROVEMENT}

The main aim of the Election Observation Centre was to facilitate and support the observation of the 1997 Kenya elections by the diplomatic missions. In particular its task was to coordinate the election observation by advising where, when and how to observe the elections.

The EOC performed all of these specific tasks requested by the DDDG. Throughout the observation period the missions were provided with maps and constituency profiles with information on candidates and specifics of their constituencies. Also, practical information was forwarded on accommodation and transport. The EOC frequently contacted (most of) the political parties, individual politicians and domestic observer organizations (the IED, NCGK and Catholic Justice and Peace Commission, Kenya Human Rights Commission, among others). For logistical matters the EOC contacted the Electoral Commission of Kenya (for example on provision of the Kenya Election Manual and the location of polling stations). It is thought that the coordination of the missions' activities resulted in better reporting and more knowledge and understanding of the Kenya 1997 elections as compared to the 1992 observation exercise. The idea to optimize the availability of manpower and financial means and to share information gathered by the individual missions to get detailed and insight on the preparation period for the vote and the voting process on election day itself materialized rather well.
Still, there is room for improvement. Among the main problems experienced during the period of coordination and observation, two should be singled out:

a) problems within the operations of the Election Observation Gentre (internal problems);

b) problems outside the operations of the Election Obscrvation Centre (external problems).

It should be kept in mind that there is sometimes no clearcut division between these two types of problems. Also, one should keep in mind that some of the problems experienced are due completely to the experimental character of this project.

\section{Problems in Relation to the Operations of the Election} Observation Centre

The mixed professional background of the EOC members (historian, geographer, political scientist, human rights lawyer), their knowledge of the country and its people, and experience in election observation allowed for addressing the broad variety of tasks needed to coordinate the observation activities. Still, some issues need attention:

- The late announcement of election day is considered to be a major factor in frustrating a timely, clear and ovcrall comprehensive start of the Election Observation Centre. The coordinators arrived rather late and at separate moments.

- For a centre without an official overall leader, the Plan of Action proved to be a very useful tool. It showed in detail deadlines to be matched, tasks to be performed and meetings to attend. It assisted also in the communication between the coordinators, who at times themselves were out in the field observing.

- A total of four people is not sufficient to run the EOC. There is, in particular, tension between coordinating tasks and observing duties. In that sense it should be mentioned that the EOG profited very much from staff members that volunteered their services.

- In principle, the tasks within the Cientre had been divided between the coordinators on a regional basis. Yel, because of lack of coordinators some areas were not specifically 
assigned (for example, Northern Rift and North of Eastern). The initial idea to coordinate all observations in one region under one person did not materialize. In practice, it turned out to be more effective to start from the perspective of linking EOC staff to specific embassies. At certain moments this meant that the logistics workload prohibitcd a thorough analysis of the elections.

- The political parties of Kenya are not well organized. As a result, the provision of information to the missions by the EOC was seriously hampered and time consuming. Campaign meetings in particular suffered a lack of detailed information for observers because dates and venues were either known very late or changed at the last moment.

Some recommendations on the division of labour within the EOC are the following:

- Timely arrangements should be made for recruitment of coordinators and other members of staff;

- Preferably coordinators and staff members should have a mixed professional background;

- Coordinators and staff members should be familiar with Kenya and its politics;

- Coordinators should be stationed at the EOG office; modest travelling is recommended;

- Budget for a personal assistant at the EOC to each coordinator to share the workload. Having a good knowledge of Kenya (its geography) and having a wide network of contacts is an advantage in assuring the collection of up-to-date information (logistics as well as content), especially for the more remote areas. In this respect, a local assistant is very helpful;

- Lists of names and contact addresses of all local coordinators should be made available to the EOC and vice versa. Local observers should play a more profound role in indicat ing to the international observers certain hot-spot areas.

\section{Problems in Relation to the Deployment of DDDG \\ Missions}

First and foremost, note that elthough 22 missions and two international organizations were united in one group of donors, they still showed a broad diversity concerning:

- (extra) financial means available;

- total personnel avarlable;

- flexibility in supplying personnel;

- knowledge of Kenya and its politics;

- understanding of the (particularities of the) constituency representation system (Westminster 'winner-takes-all' system);

- devotion and interest in careful observation;

- willingness to share information;

- involvement (otherwise) in the elections (for example, supporting domestic observers).

The above mix of characteristics results in a continuum where we find, on the one extreme, countries that provide financial means and many flexible, knowledgeable and devoted persons, while on the other extreme, missions that lack in all of these aspects. In some cases, national law or politics apparently prohibits a full participation in the diplomatic observation cxercise (for example, France, UK and Germany). In others, it is because these missions are small and/or not so knowledgeable concerning Kenyan politics. With respect to a lack of personnel we should mention that Denmark and Norway were able to overcome the rather limited size of their embassy staff by providing international observers from their countries. However, the Scandinavian observers only arrived some two weeks before the general elections. ${ }^{10}$ Finally, some countries were to a larger extent involved in the election observation exercise because they financed most of the costs of the EOC (notably the Danes, Swedes, Finns, Swiss and Dutch missions) or assisted by providing equipment and housing (Japanese and Australians). Likewise, and even more costly, some missions (Denmark, the Netherlands, Sweden and UK) enabled the recruitment and training of the local observers by providing US $\$ 1.5$ million to three Kenyan NGOs (the National Council of Churches of Kenya, the Catholic Justice and Peace Commission, and the Institute for Education in Democracy). finally, the UK was also involved in the elections by way of British companies providing ballot boxes and ballot papers. It should be noted that this aspect resulted in the British High Commission, in the view of some groups in Kenyan society, being partisan on one side. 
The following observations have been made:

Flexibility in deployment of international observers is a necessary precondition in a situation where the full and constan coverage of all constituencies is not possible. In the case of the Kenya 1997 elections approximately 30 observers were available in the period up to election day, 29 December. This means that even if they were able to cover two constituencies at a time, only about 30 per cent of the areas could be visited. By directing observers to 'most-needed' venues the most effective use is made of the manpower available and the quality of the overall observation exercise can be enhanced. Some countries, notably the Dutch, opted for a flexible attitude towards deployment of personnel. However, a flexible set-up of election observation also brings along some disadvantages, for the mission and for the EOG. The short intervals between party primaries, nomination day, campaign period and the actual election day, and the preparations needed to guide the observers, call for a fixed deployment schedule. When this is not possible or not wanted, a disproportionate amount of time has to be devoted to making last-minute enquiries and arrangements in practical matters (transport, accommodation) and also regarding content (up-to-date newspaper cuttings, copies of area profiles, former observation reports, maps). The risk of such late arrangements on the side of the diplomatic missions is that at the crucial last moment transport and manpower are not available. Likewise, for the EOC it means that fulfilling the above requirements leaves less time for analysis of observation reports and getting/ keeping in close contact with political parties, media, local groups, and so on.

As a result of this mixture in capabilities, attitudes and interests, especially in the period proceeding 29 December, only a small core group of countries performed most of the observations. For example, campaign and nomination observations were foremost left to UK, Denmark, Sweden, Canada and the Netherlands. The latter country was at one time responsible for one-third of all observers! In some respects this is the result of some missions being rather small. On the other hand, a country like the USA, having a huge observing capacity, opted not to cooperate closely with the EOG.

The mixed background of the DDDG missions also interfered with the final phase of the election observation: reporting.
Regrettably, the final report provided to the DDDG missions to be made public. The delay must have frus列 trated other missions, because according to informad handed to the Daily Nation newspaper, one of the embassies had handed to one of the Nation's reporters the 'serious irregularities' document. In the end, the delay in presenting the full results of the ment. In the end, the delay international election observation backfired on the donor community, and on the British in particular (see for example, Economic Review, 26 Jan. 1998: 24-6: 'Donor Conspiracy - Western Economic Review, 26 Jan. 1998: 24-6: 'Donor Cionspiracy - Wester. 1998 Countries Opt to Hide Election Findings', and 23 Feb. 1998 25-6: 'The Truth Is Out - Embassies of the Major Western Donor Countries Altered International Observers'Report').

The following recommendations concerning the deployment of DDDG missions could be made:

- Allocate one contact person plus one or two assistants at the embassy.

- Provide in advance, and update constantly, an overview of availability of personnel.

- Preferably locate diplomats in areas they are familiar with, within a set-up that starts from a 'flexibility' approach.

- At mission level, there should be a sharing of information by the diplomatic observers by exchanging copies of obserby the diplomatic observer meth vation reports and/or small meetings before and after each phase in the elections. Likewise, observers should contact directly and share information with colleagues who visited directly and share information with colleagues who vout the a constituency earlier or are very knowledgeable about the area.

- Local observer groups have been of major assistance to the EOC's activities in providing background data on specific areas and people. These groups are capable of playing the areas and people. These onset role of the memory of election observation. Before the 01992 of the elections they shared their experiences from the 1992 elections with the ever-rotating diplomats. Still, collaboration between the two groups of observers should be imtion between the two groups of observers be part of any proved. " Support to these groups should be part of any observation exercise in Africa.

to be among the first priorities.

- Make sure that embassies' means of transport are claimed in advance irrespective of the destination and exact dates of travel. 
- Deploy drivers in such a way that they are able to vote on election day in the constituency where they arc rcgistered.

- Discuss, check and counter-check the statements made in the final report by the donor community. Be as sober as possible in claiming irregularities. Be careful in using information, including election results from the local newspapers. ${ }^{12}$ However, there is no need to use vague formulations out of fear of interfering with possible election petitions. The $s u b$ judice rule does not apply to the donor's report. Publication of the report should not extend beyond a period of three weeks after election day, and should be made available to the Kenyan public at large.

- In general, it is recommended that missions of former colonial rulers should not head the donor community's observations. This, in particular, includes the writing up of the final report. Likewise (private companies of) former colonial rulers should be extremely reluctant to be involved in the provision of ballot boxes and ballot papers. The reason is that, notwithstanding the quality of the services provided (for example, no mistakes on ballot papers), interested groups will always point, rightly or wrongly, to the former close links and potential interests of the former colonizing country.

- It should be realized that in years to come other diplomats will be present at the foreign missions. To prepare these observers, a video was made for the Dutch Embassy showing, among other things, the election and count in Kajiado Central Constituency. This video should be used in training diplomats in coming elections.

\section{CONCLUSION}

In conclusion it must be stressed that the experiment of a new model of international election observation in Kenya has largely been successful. The combination of a small group of professional, academic election observation coordinators, most of them Kenya specialist, and of having a large political network built over many years, together with a large group of diplomatic observers stationed in Kenya, having specific political and social networks, was helpful in collecting detailed information on recent political developments there. It is important to realize that no other model is able to provide this unique blend of relevant information-gathering networks. ${ }^{13}$

In short, the main positive aspects of the Kenyan 'EOGdiplomats' model are:

- Diplomats are familiar with the area, the population and politics of the country.

- The use of diplomats as international observers is very cost efficient. In some respects it is part of their daily job, while others spend their free time. The EOG running costs are estimated at US $\$ 30,000$ (excluding salaries/DSA of the coordinators).

- Election observation is done over a long period, allowing for a better understanding of the election process itself as well as further enhancing the diplomats knowledge of Kenya.

- Cooperation and sharing of information between diplomatic missions as well as with Kenyan society at large (political parties, NGOs, clergy) is strengthened and might also contribute to a better knowledge of the country.

- The unified and coordinated observation exercise results in a single donor observation report. This enhances chances of their voice being heard and appropriate action taken by all parties involved.

Negative outcomes of the experiment are:

- Too large a variety in attitudes of embassies towards the observation of the elections. In the end it all comes down to the interest shown and time and energy devoted by the local diplomats in the election observation exercise.

- Too long a delay in publishing the final report. This created irritation between diplomatic missions and, in the end, resulted in two versions circulating in the Kenyan press. This is likely to be (mis)interpreted by the Kenyan public.

Among the main objections made to diplomats is that they are not willing to speak out clearly and loudly if irregularities are observed. One should, however, realize that the group of diplomats is diverse. The Kenyan experiment has shown that as a result it is most unlikely that the final verdict will not be made public. In the group of foreign missions some will not allow this to happen. Moreover, the group of coordinators and 
the domestic observers also act as a kind of watchdog. finally, some of the negative aspects of the model can be overcome in time, while the advantages far outweigh the possible problems. Therefore, implementation of this model of election observation in other African countries is sincerely recommended. A prerequisite is complementary assistance in the recruitment and training of domestic observers. A nation-wide coverage of polling stations by domestic observer groups is an integral element of the new model.

In summary, the new approach of election observation by diplomats in collaboration with a group of professional coordinators is more cost efficient, sustainable and proficient than the old model of flying in election observers from abroad. ${ }^{14}$ first, diplomats remain in the country and continue to meet, discuss and make policies relevant to the host country. This will in the short and middle run strengthen the consistency of the Western donors' reactions to the process of democratization: the donors' 'memory' is more profoundly prescnt for the government of the host country. Second, contacts between the diplomatic community, civil society and political parties (opposition and government alike) will be intensified. Third, support to domestic observer groups allows for the existence and further development of a source of information on local politics and election observation. This local 'memory' is also of major importance in preparations for coming elections.

To some countries (host and observing alike) this might be a less welcome scenario. ${ }^{15}$ As a code of conduct for the host country it should allow resident diplomats to observe the elections, while observing countries should likewise refrain from flying in observers from abroad. This scenario should only be employed as a last option if an insufficient number of local diplomats are available to observe the elections in a substantial and profound way. These observers, who should all have a good knowledge of local politics, should follow the instructions and guidelines explained in training sessions set out by the coordinating Election Observation Centre. They should report to the $\mathrm{EOC}$, and refrain from individual statements.

I strongly believe that under the old model chances of legitimizing fraudulent elections are higher. As a result, this ap- proach should be abandoned altogether. The new model should become an esscntial element of the new code of conduct for election observation, to an extent that failure to implement it renders, at beforehand, any election 'not free and fair'.

\section{NOTES}

I am grateful to Mr N. Braakhuis and Dr F. Grignon for information and comments on a draft version of this chapter.

1. DDDG members are Australia, Austria, Belgium, Canada, Czech Republic, Denmark, finland, France, Germany, Greece, Hungary, Italy, Japan, the Netherlands, Norway, Poland, Portugal, Spain, Sweden, Switzerland, United Kingdom, United States, European Union and UNDitzer

2. The staff members of the EOG consisted of four coordinators: Dr Judith Geist (USAID), Prof. Palle Svensson (Denmark - Aarhus University), Dr David Throup (British Foreign Office) and Dr Marcel Rutten (Netherlands - ASC). In addition, full-time assistance was provided by Ms. Catherine Duhamel (Canada) and Ms. Sabitha Raju (UK), while Dr Francois Grignon (France - IFRA), Mr Charles Hornsby (UK while Dr François Gr Njonga (Kenya - SNV) and Mr Ralph Peters - Shell), Mr Peter Njenga (Kenga's (Germany) contributed to the EOC's operations for short periods. Overall logistics and financial management was in the hands of Mrs Laurie Rees (UK).

3. The legal parameters required that parliament be dissolved no later than 25 January 1998 and an election held within 90 days.

4 The British, after some hesitation because of directions from the London office, joined later. They realized that USAID and the EU politLondon offcc, join in ical counsellors funded Election Observation Centre, and delegated Mr David Throup, a Foreign Office-employed scholar who specialızes on Kenya and elections in Africa, to the secretariat, as well as Ms. Laurie Rees as office manager. No direct British funds were made available, however, as they opted to finance local observer groups only.

5. See, for example, Kenya Human Rights Commission, Kayas of De, for exas Klote in Coastal Kenya (Nairobi 1997).

6. In addition, Dr Francois Grignon (France - IFRA) should be menIn addition, Dr François Grignon (France Ukamaban. He also made available detailed maps of the constituencies. Mr Charles Hornsby, a former arde to David Throup in 1992, had come from Ghana to assist the EOC during the last week of Decembel and early days of January 1998. He assisted in analysing election result by the provision of figures showing turn-out, presidential and parliamentary results per province, and the like. David Throup (by 
interviewing Paul Muite) and Marcel Rutten (meetings with Richard Lcakey) did information-gathcring from Safina. Rutten also was in close contact with Ford-K politicians and activists.

7. These problems were particularly acute in the local government elections but affected some parliamentary and presidential polls as well. In some polling stations ballot books were not delivcred, or the names of candidates and symbols of political parties were missing or wrongly printed.

8. It is also noteworthy that the result announced by the returning officer, 18,590 for KANU against 17,721 for DP, which was also broadcast on radio and appeared in the print media, conflicted with the result on dorsed by all opposition partic and obsia, conflicted with the result en dorsed by all opposition parties and observers (17,829 for DP against 17,790 for KANU) as well as with the official result published by the Electoral Commission of Kenya of 17,882 (KANU) to 17,877 (DP).

9. The term sub judice literally means 'under judicial consideration' Derived from it is the Sub Judice Rule: It is undoubted law that, when litigation is pending and actively in suit before the court, no one shall comment on it in such a way that there is a real and substantial danger of prejudice to the trial of the action (see Nowrojee 1997: 1).

10. In many constituencies, indeed, in perhaps two-thirds, the party primary is as, if not even more, important than the general election in selecting Kenya's future Members of Parliament and local councillors. In that respect, we need to conclude that the presence of international observers was very crucial. However, reasoning from the same argument, the number of international observers during these days should be further increased in coming elections.

11. This remark is made notwithstanding the fact that the domestic observers made premature statements on the 'free and fairness' of the elections. At the same moment problems came to a head in Westlands, the domestic observers gave a press conference some 500 metres from the Westlands Counting hall, declaring that 'the results do on the whole reflect the wishes of the Kenyan voters'. This also increased tensions betwcen and within the three participating organizations, the IED, CJPC and NCGK

12. In the initial analysis based on election results published in the local daily newspapers it seemed as if there were an above 100 per cent turnout in Molo Constituency. Later it became clear that the Molo number of registered voters had been interchanged with the one of Kuresoi. Likewise, the total number of votes cast and the number of valid votes were sometimes mixed up in the daily newspapers. This interferes especially with the analysis of the number of votes cast for the presidency compared to those cast for the parliamentary election. fina offial figures of the checked checked carefully. For example, in the Presidential Results per Constituency overview published on 14 January the figures for Kipipiri are the ones of Maragwa. These figures now suggest a turn-out of 105.87 per cent. Also, the results for Moi and Ngilu in Yata Constituency have been interchanged to the detriment of the latter.

13. (Political) diplomats have contacts with journalists, politicians, human rights groups, international donors, and the like. This amounts to an up-to-date package of views and relevant information which aids profound understanding of the polltics and main issues at stake, and is helpful in streamlining the clection observation exercise.

14. The call to do away with election tourism and for a large and welltrained group of international observers can be heard nowadays. Yet it is my opinion that a group of some 100 professional international observers, moving from one election to another, will not be able to form detailed and up-to-date local contacts and obtain specific country knal knowledge. This model cannot offer the same quality of observan Even more importantly, this model will not be able to provide hands for a follow-up to the strengthening of the democratization process, as the mix of local diplomats and a small group of country specialist coordinators would.

15. While observing in Narok District a local MP candidate and incumbent Minister of the Cabinet told two local observers that if it was to him they would not be allowed to observe the elections'. Likewise, the Kenyan rovern 1992 elections (see Geisler 1993: 614).

\section{REFERENCES}

Andreassen, B. 1998. 'Report from a Post-election Visit to Kabarnet Town, Baringo Central' (Nairobi).

Andreassen, B, G Geisler and A. Tostensen, 1992. 'Setting a Standard for Africa? - Lessons from the 1991 Zambian Elections', Report 1992: 5 (Bergen: Chr. Michelsen Institute).

Barkan, J.D. 1993. 'Kenya: Lessons from a Flawed Election', Journal of Democracy 4(3): 85-99.

DDDG, 1998. 'Final Report Kenya General Elections 1997' (Nairobi: the Donors' Democratic Development Group).

Duhame C. 1997. Duplomatic Election Observers Field Guedance (Nairobi: Donors' Democratic Development Group Election Observation Centre, Dec.).

ECK, 1997. Press Conference, 31 Dec., Nairobi.

EGK, 1998. Press Conference, 4 Jan., Nairobi.

ECK, 1998. Parliamentary Election Results per Constituency (Nairobi, 11 Jan. 1998).

Elklit, J. and P. Svensson, 1997. 'The Rise of Election Monitorng: What Makes Elections Free and Fair?' Journal of Democracy 8(3): 32-46.

EOC, 1997. The Party Primaries (Nairobi).

EOC, 1998. 'Kenya General Elections 1997 Final Report - for Donors' Democratic Development Group' (Nairobi).

Democratic Development Group' (Nairobi).
Garling, M. and J. Geist, 1997. 'Diplomatic Election Observation Secretariat Proposed Structure and Operation' (Nairobi)

Geisler, G. 1993. 'Fair? What has fairness got to do with it? Vagaries of Election Observations and Democratic Standards', Journal of Modern African Studies 31 (4): 613-37.

IED, 1996. The Electoral Environment in Kenya - a Research Project Report (Nairobi: Institute for Education in Democracy). 
IED, GJPG and NCGK, 1998. 'Final Statement on Kenya 1997 General Elections', Nairobi, 3 Jan.

KHRC, 1997. Kayas of Deprivation, Kayas of Blood - Violence, Ethnucty and the State in Coastal Kenya (Naurobi: KHRC).

KHRC and Article 19, 1997. 'Elections '97: Media Watch - Media Monitoring in Kenya, July-December 1997 Reports' (Nairobi).

Mulei, C, 1996 ' 'Historical Perspectives of Elections in Kenya', in the Institute for Education and Democracy, The Electoral Environment in Kenya - A Research Project Report, Instztute for Education in Democracy (Nairobı: IED), pp. 24-39. NEMU, 1993. The Multi-Party General Elections in Kenya - 29 December 1992, the Report of the National Election Monitoring Unit (Nairobi).

Nowrojee, P. 1997. 'The Sub-Judice Rule', paper presented at the workshop on court/legal reporting of the Media Institute, held at the Professional Centre, Nairobi, 21-2 Nov. 1997.

Rutten, M. 1998. 'Kenya General Elections 1997 - Implementing a New Model for International Election Observation in Africa', Draft Report submitted to Royal Netherlands Embassy - Nairobi / African Studies Cientre Leiden, March.

\section{Periodicals Consulted:}

Afruca Confidential 33(25), 1992, 'Kenya: Democracy Could be the Loser'. Afruca Confidential 34(1), 1993, 'Kenya: Failing the Democracy Test'.

Economic Reveew (Nairobi), 26 May 1997, p. 30, 'Elections '97: Invalid Cards? New Voters Cards May Not Comply with the Law'.

Economic Review, 30 June 1997a, p. 20, 'Registration Controversy - Kajiado North Luos Claim Bias'.

Economic Remew, 26 Jan 1998 , 24-6, 'Donor Conspiracy - Western Countrics Economic Revneve, 26 Jan. 1998, pp.
Opt to Hide Election Findings'

Economic Review, 23 Feb. 1998a, pp. 25-6, 'The Truth Is Out - Embassies of the Major Western Donor Countries Altered International Observers' Report'. Weekly Review (Nairobi), 12 March 1993, 'Nemu's Verdict on the Polls'. 